\title{
Lymphoid tissue inducer cells: pivotal cells in the evolution of CD4 immunity and tolerance?
}

\section{Peter J. L. Lane*, Fabrina M. Gaspal, Fiona M. McConnell, David R. Withers and Graham Anderson}

MRC Centre for Immune Regulation and College of Medical and Dental Sciences, University of Birmingham, Birmingham, UK

Edited by:

Brigitta Stockinger, MRC National

Institute for Medical Research, UK

\section{Reviewed by:}

Andrew McKenzie, Medical Research

Council Laboratory of Molecular

Biology, UK

Eric Vivier, Centre d'Immunologie de

Marseille-Luminy, France

${ }^{*}$ Correspondence:

Peter J. L. Lane, Department of Immunity and Infection, Birmingham Medical School, MRC Centre for Immune Regulation and College of Medical and Dental Sciences,

University of Birmingham, Vincent Drive, Birmingham B178QB, UK.

e-mail:p.j.l.lane@bham.ac.uk
Phylogeny suggests that the evolution of placentation in mammals was accompanied by substantial changes in the mammalian immune system: in particular lymph nodes and CD4 high affinity memory antibody responses co-evolved during the same period. Lymphoid tissue inducer cells (LTi) are members of an emerging family of innate lymphoid cells (ILCS) that are crucial for lymph node development, but our studies have indicated that they also play a pivotal role in the long-term maintenance of memory CD4 T cells in adult mammals through their expression of the tumor necrosis family members, OX40- and CD30-ligands. Additionally, our studies have shown that these two molecules are also key operators in CD4 effector function, as their absence obviates the need for the FoxP3 dependent regulatory $T$ ( $T_{\text {regs }}$ ) cells that prevent CD4 driven autoimmune responses. In this perspective article, we summarize findings from our group over the last 10 years, and focus specifically on the role of LTi in thymus. We suggest that like memory CD4T cells, LTi also play a role in the selection and maintenance of the $\mathrm{T}_{\text {regs }}$ that under normal circumstances are absolutely required to regulate $\mathrm{CD} 4$ effector cells.

Keywords: memory, effector, lymphoid tissue inducer cells, lymph nodes, regulation

\section{INTRODUCTION}

As their name suggests, lymphoid tissue inducer cells (LTi) orchestrate the development of lymphoid tissues, as has been reviewed elsewhere (Mebius, 2003; Eberl, 2005). Here, we consider both the wider importance of LTi in mammals, and the likelihood that their contribution to modern immunity originated in early innate protection. Key characteristics of LTi that extend their relevance beyond lymphoid tissue development are: their persistence into adulthood in both mice (Kim et al., 2003) and men (Kim et al., 2011), and their central role in T cell independent antibody production in the gut (Tsuji et al., 2008). Table 1 summarizes the current understanding of LTi phenotypes.

Although LTi are not very numerous, their location at sites of lymphocyte traffic puts them in position to interact with CD4 cells as they recirculate between blood and lymph. In spleen, LTi are tightly associated with mucosal vascular addressing cell adhesion molecule 1 (MAdCAM-1) expressing cells located in the marginal sinus and bridging channels, which have been identified by imaging studies to be points of entry for splenic lymphocytes (Bajenoff et al., 2008). In lymph node, LTi are located in the subcapsular sinus and interfollicular areas where intranodal lymphatics drain lymph to the medulla and efferent lymphatics, again associated with MAdCAM-1 expressing cells, and again positioned to intercept incoming lymphocytes (Figure 1).

Because of their location in cryptopatches adjacent to proliferating epithelial precursors in the lamina propria of the gut, and because of their constitutive expression of interleukin-22 (Takatori et al., 2009), linked with integrity of epithelium (Wolk et al., 2004; Aujla et al., 2008; Satoh-Takayama et al., 2008), we have suggested that LTi might have been lymphocyte participants in an ancestral innate immune system that antedated adaptive $\mathrm{T}$ and $\mathrm{B}$ cell dependent immunity in jawed vertebrates (Lane et al., 2012). In support of this hypothesis, it is known that key transcription factors required for LTi development (Ikaros, Georgopoulos et al., 1994; Tox, Aliahmad et al., 2010; ROR $\gamma$ t, Flores et al., 2007; and Id2, Yokota et al., 1999) have zebrafish orthologs, and associated genes show synteny between the human and zebrafish genomes. Teleost genomes also harbor orthologs of the transcription factor, AHR (Hahn et al., 1997), which is required for the expression of interleukin-22 (IL-22; Veldhoen et al., 2008), and IL-22 is also found in zebrafish genomes, clustered with interferon gamma (IFN $\gamma$ ) and interleukin 26 (IL26), as it is in higher mammals. Therefore, the genes essential for the generation of IL22-expressing LTi were likely to have been present in the ancestral immune system.

However, in addition to these phylogenetically "old" genes, LTi also express high levels of many tumor necrosis superfamily members (TNFSF), some of which are absent in teleost genomes (Glenney and Wiens, 2007). For instance, the lymphotoxin beta receptor (LT $\beta R$ ) ligands on LTi that program lymph node development (Futterer et al., 1998) are exclusive to placental mammals, but the RANKL expressed by LTi as part of lymph node development also occurs in teleost genomes (Kong et al., 1999). Additionally, our work has shown that adult LTi are distinguished from the neonatal population by their expression of high levels of OX40 ligand (OX40L, TNFSF4; Kim et al., 2011) and in mouse CD30L (TNFSF8; Kim et al., 2003). Our studies have found that CD4 $\mathrm{T}$ cell memory function is highly dependent on signaling through both OX40 and CD30 (Gaspal et al., 2005) suggesting additional roles for LTi in the mediation of adaptive 
Table 1 | Phenotypes of embryonic and adult LTi in human and mouse.

\begin{tabular}{|c|c|c|c|c|c|}
\hline & & \multicolumn{2}{|c|}{ Mouse } & \multicolumn{2}{|c|}{ Human } \\
\hline & & Embryonic LTi & Postnatal LTi & Embryonic LTi & Postnatal LTi \\
\hline & IL-17A & + & + & + & Low \\
\hline & IL-23R & + & + & + & + \\
\hline Transcription & $\mathrm{ROR} \gamma \mathrm{t}$ & + & + & + & + \\
\hline & AHR & + & + & + & + \\
\hline Surface & CD3 & - & - & - & - \\
\hline \multirow[t]{4}{*}{ Marker } & CD4 & $+/-$ & $+/-$ & - & $-($ Low $)$ \\
\hline & CD117 & + & + & + & + \\
\hline & IL-7R $\alpha$ (CD127) & + & + & + & + \\
\hline & IL-2R $\alpha$ (CD25) & + & + & + & + \\
\hline \multirow{2}{*}{ TNFSF } & $\mathrm{TNF}, \mathrm{LT} \alpha, \mathrm{LT} \beta$ & ++ & ++ & ++ & ++ \\
\hline & DR3 (TNFRSF25) & + & + & + & + \\
\hline Chemokine & CXCR5 & + & + & + & + \\
\hline \multirow[t]{2}{*}{ Receptor } & $\mathrm{CCR7}$ & + & + & + & + \\
\hline & CCR6 & + & + & + & + \\
\hline
\end{tabular}

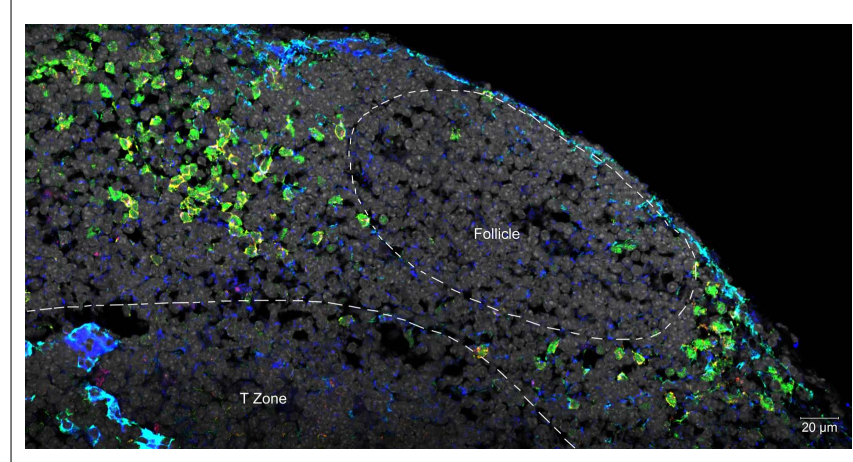

FIGURE 1 | Confocal micrograph of mouse mesenteric lymph node, showing the localization of LTi at the margins of follicles and in association with the stromal element MadCAM. Normal lymph node sections were stained with fluorescent markers for Ror $\gamma$ t (green), IL-7R $\alpha$ (Yellow), MadCAM-1 (blue, turquoise), and cell nuclei (gray).

CD4-dependent immune responses. OX40L and CD30L and their respective receptors are found in birds and mammals, which share a common ancestor some 300 mya, but not in teleosts (Glenney and Wiens, 2007).

\section{PHYLOGENETIC LINKS BETWEEN THE DEVELOPMENT OF LYMPH NODES AND CD4 MEMORY}

We have previously noted that both lymph nodes and CD4 memory antibody responses evolved in the same developmental window: after the divergence of monotremes from other mammals some 166 mya, and before marsupials and eutherians split approximately 148 mya (Warren et al., 2008). The key gene missing in monotremes is the LT $\beta$ R gene, which is obviously crucial for LTidependent lymph node development, but which is also essential for generating high affinity CD4-dependent memory antibody responses (Futterer et al., 1998).

\section{OX40L AND CD30L EXPRESSION BY LTi SUPPORTS CD4 MEMORY BUT IS NOT NECESSARY FOR CD4 EFFECTOR FUNCTION}

OX40 and CD30 are TNSF receptor family members expressed chiefly on activated CD4 T cells, but they can also appear on CD8 T cells and some non-lymphoid cells (Watts, 2005). Many studies have examined the phenotype of mice individually deficient in OX40 and CD30 (Croft, 2009), but because of the coexpression of their ligands on LTi, and the sharing of their signaling pathways, indicating possible redundancy, we chose to generate mice deficient in both signals (dKO) by interbreeding CD30 and OX40-deficient mice.

Not only was affinity maturation of the antibody response in the double deficient mice grossly impaired, but there was abrogation of memory antibody responses to CD4-dependent protein antigens (Gaspal et al., 2005); the profound effect on CD4 T cell performance was in contrast to general conservation of CD8 function. By crossing $\mathrm{dKO}$ with $\mathrm{CD} 4 \mathrm{~T}$ cell receptor transgenic ( TcRtg) mice, we were also able to show that primary antigen-driven proliferation of dKO or singly deficient OX40 or CD30 deficient TcRtg CD4 T cells was normal, but that their survival was defective both in vivo and in vitro. Second, this deficit was not restricted to CD4 T cell help for B cells, as $\mathrm{dKO}$ mice were also deficient in their capacity to clear Salmonella, a Th1-dependent CD4 response (Gaspal et al., 2008). Lamina propria CD4 T cells, previously shown to harbor memory CD4 populations (Reinhardt et al., 2001) were also dependent 
on OX40 and CD30 signals (Withers et al., 2009). In unpublished experiments using LTi-deficient mice, we have found that in their absence memory does not persist, showing that it is the expression of OX40L and CD30L by LTi that supports CD4 memory (see "Are LTi required for the maintenance of memory" below).

\section{OX40 AND CD30 ARE ESSENTIAL FOR CD4 DRIVEN} AUTOIMMUNITY IN FoxP3 ${ }^{K 0}$ MICE, BUT LTi ARE NOT

FoxP3 is the transcription factor controlling the development of $\mathrm{T}$ regulatory $\left(\mathrm{T}_{\text {regs }}\right)$ cells, which temper $\mathrm{T}$ cell effector responses (Fontenot et al., 2003). In mice and men, deficiency of FoxP3 causes fatal CD4 driven autoimmune disease (Bennett et al., 2001; Wildin et al., 2001). Mice lacking FoxP3 (FoxP3 ${ }^{\mathrm{KO}}$ mice) die of their autoimmunity at between 3 and 5 weeks of age; to test the requirement for OX40 and CD30 in this CD4 effector-driven disease, we crossed $\mathrm{dKO}$ mice with FoxP3 ${ }^{\mathrm{KO}}$ mice. The outcome was dramatic: $\mathrm{dKO}$ FoxP3 ${ }^{\mathrm{KO}}$ did not develop autoimmune disease; they breed successfully and have a normal lifespan (Gaspal et al., 2011).

The expression of OX40L and CD30L is not restricted to LTi, as activated B cells, dendritic cells (DCs) and other non-hemopoietic cells can express them, but the expression on LTi is high and does appear to be independent of antigenic stimulation. To test whether FoxP $3{ }^{\mathrm{KO}}$ disease was LTi-dependent, we crossed FoxP $3{ }^{\mathrm{KO}}$ mice with $\mathrm{ROR} \gamma \mathrm{t} \mathrm{KO}^{\mathrm{KO}}$ mice (lacking LTi, but with essentially normal $\mathrm{B}$ and DCs) to generate FoxP $3{ }^{\mathrm{KO}} \mathrm{ROR} \gamma \mathrm{t}^{\mathrm{KO}}$ mice. Although the onset of FoxP3 ${ }^{\mathrm{KO}}$ disease was delayed slightly (our unpublished observations), these mice still developed fatal lymphoproliferative disease, indicating that expression by cells other than LTi of OX40L and CD30L was sufficient to support autoimmune effectors (our unpublished observations).

\section{ARE LTi REQUIRED FOR THE MAINTENANCE OF CD4 MEMORY?}

Our work on FoxP3 dependent autoimmunity (above) indicated that CD4 effector function was dependent on OX40 and CD30, but that the abundance of their ligands on LTi was not by itself driving effector responses. Another context for the relevance of the high constitutive expression of OX40L and CD30L on LTi is the LTi- and LT $\beta$ R-dependent development of lymph nodes and its co-evolution with the capacity to evoke CD4-dependent memory antibody responses (Lane et al., 2005). So are LTi required for CD4 memory? Supportive evidence for this hypothesis is our finding that ROR $\gamma \mathrm{t}^{\mathrm{KO}}$ mice that are without LTi behave like CD30 OX40 dKO mice: they fail to evoke memory antibody responses, although their primary antibody responses are normal (Withers et al., 2011). In contrast to dKO mice, however, affinity maturation in ROR $\gamma \mathrm{t}^{\mathrm{KO}}$ mice was no different from WT controls, indicating that OX40L (Kim et al., 2005) and/or CD30L signals from B cells were sufficient for this aspect of the $\mathrm{B}$ cell response.

We have also gone on to test directly whether the absence of LTi impairs the generation of CD4 memory using CD4 tetramers developed by the Jenkins laboratory (Pepper et al., 2010), and this again supports the contention that LTi are likely candidates for the provision of these signals to memory CD4 T cells (our unpublished data).

\section{LOCATION OF LTI AT SITES WHERE CD4 LYMPHOCYTES RECIRCULATE}

As described in our introduction, the tissue locations of LTi make them very accessible to recirculating lymphocytes. This is relevant to what we propose is an important regulatory mechanism involving IL-7, which has a documented role in the support of CD4 memory (Surh and Sprent, 2008). We have observed that IL7 upregulates OX40 on memory CD4 T cells (Gaspal et al., 2005), leading us to the hypothesis that when recirculating memory CD4 $\mathrm{T}$ cells encounter that IL-7-expressing stromal cell populations in lymph node and spleen (Link et al., 2007; Repass et al., 2009) they upregulate their surface expression of OX40. They are then in an appropriate state to receive support signals from the OX40L on $\mathrm{LTi}$, which are in the immediate vicinity. In this way, LTi could maintain memory CD4 cells specifically, as OX40 on CD4 effector cells is unaltered in the presence of IL-7 (Gaspal et al., 2005).

\section{CO-EVOLUTION OF CD4-DEPENDENT REGULATION AND EFFECTOR FUNCTION?}

Perhaps the most interesting aspect of our autoimmunity studies, showing that FoxP3 dependent $\mathrm{T}_{\text {regs }}$ were dispensible in mice deficient in OX40 and CD30, is the implication that $\mathrm{T}$ cell regulation is only relevant in the context of OX40 and CD30 dependent CD4 effector function. This further implies that CD4 regulation and effector function co-evolved and that the mechanism of $\mathrm{T}_{\text {regs }}$ action must operate by affecting the delivery of OX40 and CD30 signals to CD4 effector cells. We think there is a clear possibility that $\mathrm{T}_{\text {regs }}$ work by regulating the OX40 expression of CD4 $\mathrm{T}$ cells primed to become effectors. On APCs such as B cells and DCs (Kim et al., 2005), OX40L is co-expressed with the CD28ligands, and is upregulated by activation signals like CD40L from primed CD4 T cells (Ohshima et al., 1997; Brocker et al., 1999). Expression of OX40 on CD4 T cells during priming is highly CD28 (Walker et al., 1999) and IL2 dependent (Williams et al., 2007). Therefore an effective strategy for $\mathrm{T}_{\text {regs }}$ is to compete for access to CD28-ligands during priming through expression of CTLA4, the CD28 competitor, required for $\mathrm{T}_{\text {reg }}$ function (Wing et al., 2008; Schmidt et al., 2009), and now shown to actively deplete CD28ligands from the antigen-presenting surface (Qureshi et al., 2011). The significance of the mechanism of action of $\mathrm{T}_{\text {regs }}$ to our discussion of LTi is that OX40 signaling in effector T cells can be regulated without necessarily involving levels of ligand expression. This pertains directly to one feature of normal adult LTi that attracted our attention very early on: the constitutive expression of high levels of OX40L (in the absence of the CD28-ligands and CD40L), which we have since observed to be undiminished in FoxP3 ${ }^{\mathrm{KO}}$ mice (our unpublished data). This is the crux of what we believe to be the defining role of LTi in modern mammals: the maintenance and regulation of the memory pool of CD4 T cells independent of the regulation of the effector arm of the immune response. We propose that LTi are invulnerable to the regulatory machinations of $\mathrm{T}_{\text {regs }}$ due to their absence of effector costimulatory molecules, but keyed into CD4 T cell support provided by LTi by virtue of their constitutive OX40L (and CD30L) expression. 


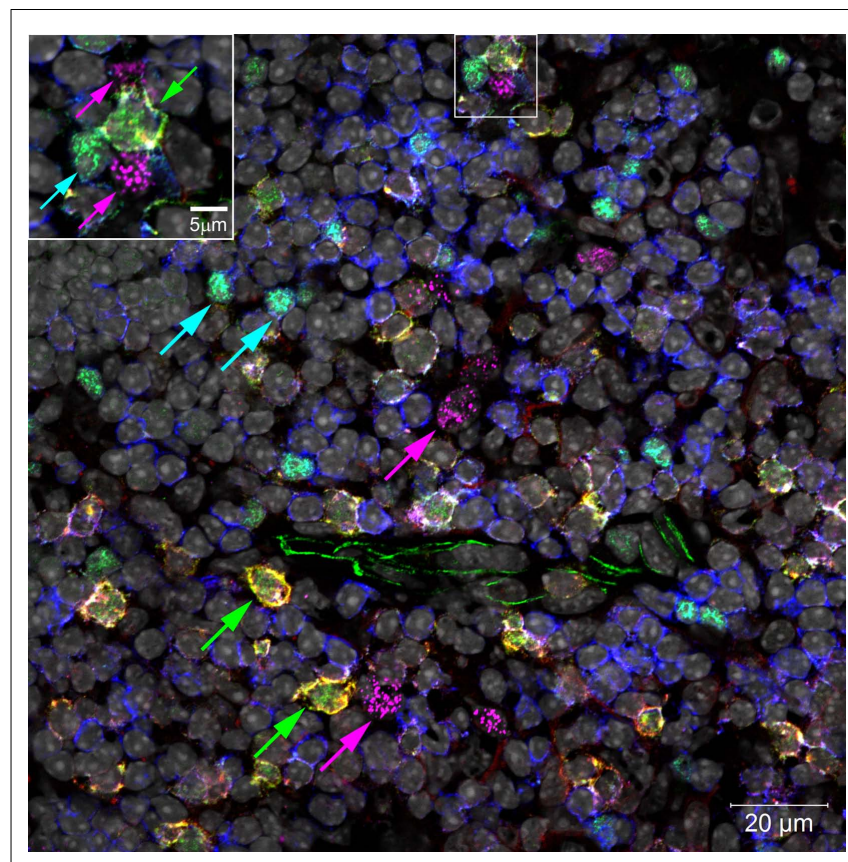

FIGURE 2 | Confocal micrograph of mouse thymic medulla, marking locations of LTi (green arrows), $\mathrm{T}_{\text {regs }}$ (turquoise arrows), and $\mathrm{AIRE}^{+}$ mTECs (magenta arrows). Inset enlarges an LTi in a cluster with two mTECs and $a T_{\text {reg. }}$. Normal thymus sections were stained with fluorescent markers for Ror $\gamma$ t (green), IL-7R $\alpha$ (Yellow), Foxp3 (turquoise), CD3 (blue), AIRE (magenta), and cell nuclei (gray).

\section{ROLE OF LTi IN GENERATION OF T CELL TOLERANCE IN THE THYMUS}

In addition to being found in lymph nodes and spleen, LTi are also found in both the embryonic and adult thymus, where they associate with medullary epithelial cells (mTECs; Figure 2). Our own studies showed that LTi cells are highly efficient regulators of the development of a subset of mTEC that are defined by expression of the autoimmune regulator (AIRE) gene (Rossi et al., 2007), which controls the intrathymic expression of peripheral tissue restricted antigens (TRAs; Metzger and Anderson, 2011). In mice, AIRE deficiency has been linked to the onset of multi-organ autoimmunity while AIRE deficient humans develop autoantibodies to self-antigens and cytokines (Aaltonen and Bjorses, 1999). Further studies on the adult thymus showed that positively selected thymocytes can also regulate $\mathrm{AIRE}^{+}$mTEC development, although mice deficient in thymocyte positive selection (Hikosaka et al., 2008; White et al., 2010) still contain $\mathrm{AIRE}^{+}$mTEC, albeit at reduced numbers, suggesting that the continued presence of LTi cells in the adult thymus may also influence mTEC development.

Of note, several TNF Receptor family members have been implicated in mTEC maturation, which fits well with reports documenting expression of various TNF receptor ligands on both LTi and positively selected thymocytes. While initial studies suggested a key role for Lymphotoxin in the regulation of AIRE $^{+}$mTEC development (Chin et al., 2003), subsequent studies have argued against this. Importantly however, despite their normal $\mathrm{AIRE}^{+}$mTEC development, LT $\beta \mathrm{R}$ deficient mice display disorganized medullary areas that have been linked to the onset of autoimmunity (Boehm et al., 2003), suggesting a pivotal but poorly understood role for LT $\beta$ R in thymus medulla formation and function. Importantly, LTi constitutively express high levels of RANK-ligand(L) (TNFRSF11a), and we showed that RANKL ${ }^{+}$ LTi trigger the maturation of RANK+ AIRE- mTEC progenitors into mature $\mathrm{AIRE}^{+}$mTEC (Rossi et al., 2007). The involvement of single positive thymocytes in $\mathrm{AIRE}^{+}$mTEC maturation can also be explained by their expression of RANKL, although CD40L - which is expressed by thymocytes but not LTi - has also been implicated (Akiyama et al., 2008; Irla et al., 2008). Thus, a scenario emerges suggesting that initial appearance of $\mathrm{AIRE}^{+}$ mTEC in the fetal period is regulated by $\mathrm{RANKL}^{+} \mathrm{LTi}$, while positively selected RANKL ${ }^{+} \mathrm{CD} 4 \mathrm{~L}^{+}$thymocytes, perhaps acting in conjunction with LTi, regulate development in the adult thymus. Interestingly, given that the neonatal period has long been known to represent a key developmental stage in the induction of $\mathrm{T}$ cell tolerance, the contribution from LTi cells to thymic medullary development in the fetal/neonatal period is likely to be critical. Indeed, the importance of AIRE mediated neonatal tolerance has recently been demonstrated by studies in which the deletion of $\mathrm{AIRE}^{+}$mTEC is temporally controlled. These findings indicate that intrathymic tolerance to AIRE-dependent peripheral self-antigens is crucial in fetal/neonatal life, and that the deletion of $\mathrm{AIRE}^{+}$mTEC in the steady-state adult thymus does not result in tolerance breakdown unless it is accompanied by T-lymphopenia (Guerau-de-Arellano et al., 2009). Collectively, these findings suggest that the induction of long lasting $\mathrm{T}$ cell tolerance is dependent on the generation of AIRE-expressing microenvironments in the embryonic thymus, which are fostered in part by LTi cells prior to the emergence of mature $\alpha \beta T$ cells. This is compatible with the view that LTi play a pivotal role not only in the generation of high affinity memory antibody responses, but are also involved in purging the emerging $\mathrm{T}$ cell repertoire of self-reactivity, both through negative selection and potentially through positive selection of $\mathrm{T}_{\text {regs }}$ specific for self-antigens.

Whereas CD4 effector cells are derived from precursors that have been purged of self-reactivity in the thymus, at least some $\mathrm{T}_{\text {regs }}$ are positively selected in the thymus on the basis of stronger TCR signals (Moran et al., 2011) and there is evidence that the niche for selection of these $T_{\text {regs }}$ is limiting (Bautista et al., 2009). Previous evidence suggested that $T_{\text {regs }}$ were selected on thymic epithelium (Apostolou et al., 2002) and evidence has also been provided for their selection on $\mathrm{AIRE}^{+}$mTecs; Aschenbrenner et al., 2007). In this regard, mTECs express many of the costimulatory molecules (CD80, CD86) expressed by the activated DCs that select naïve $\mathrm{T}$ cells into the effector and memory pools in combination with antigen-specific signals. Given that $T_{\text {reg }}$ selection in the thymus is in part CD28-dependent (Tai et al., 2005), and thymic LTi are located adjacent to mTECs (Rossi et al., 2007), it will be interesting to determine whether LTi cells are also involved in the intrathymic selection of $T_{\text {regs }}$, either directly, or indirectly through their involvement in $\mathrm{AIRE}^{+}$mTEC maturation. 


\section{ARE LTi IMPLICATED IN THE SURVIVAL OF T regs $_{\text {? }}$}

As stated above, unlike the naïve CD4 $\mathrm{T}$ cell repertoire that is largely purged of self-reactivity, $\mathrm{T}_{\text {regs }}$ are positively selected on the basis of their reactivity to self-antigens, and show evidence of having undergone strong $\mathrm{T}$ cell receptor signaling in thymus (Moran et al., 2011). Like DCs, mTECs express CD28-ligands, and therefore the costimulatory environment is more like that experienced by naïve $\mathrm{CD} 4 \mathrm{~T}$ cells when they are selected by antigen during priming in secondary lymphoid tissues. As $\mathrm{T}_{\text {regs }}$ survival depends on OX40 and CD30, it seems plausible that, like memory CD4 $\mathrm{T}$ cells, thymic derived self-antigen selected $\mathrm{T}_{\text {regs }}$ are kept alive by OX40 and CD30 signals from LTi as they recirculate through secondary lymphoid tissues. Although they lack IL-7R, characteristically expressed on memory CD4 T cells, $\mathrm{T}_{\text {regs }}$ constitutively express OX40 and to a lesser extent CD30, and therefore do not require stimulus from IL7-signals to gain access to survival signals from LTi. We are currently investigating this possibility.

\section{REFERENCES}

Aaltonen, J., and Bjorses, P. (1999). Cloning of the APECED gene provides new insight into human autoimmunity. Ann. Med. 31, 111-116.

Akiyama, T., Shimo, Y., Yanai, H., Qin, J., Ohshima, D., Maruyama, Y., Asaumi, Y., Kitazawa, J., Takayanagi, H., Penninger, J. M., Matsumoto, M., Nitta, T., Takahama, Y., and Inoue, J. (2008). The tumor necrosis factor family receptors RANK and CD40 cooperatively establish the thymic medullary microenvironment and self-tolerance. Immunity 29, 423-437.

Aliahmad, P., De La Torre, B., and Kaye, J. (2010). Shared dependence on the DNA-binding factor TOX for the development of lymphoid tissue-inducer cell and NK cell lineages. Nat. Immunol. 11, 945-952.

Apostolou, I., Sarukhan, A., Klein, L., and Von Boehmer, H. (2002). Origin of regulatory $\mathrm{T}$ cells with known specificity for antigen. Nat. Immunol. 3, 756-763.

Aschenbrenner, K., D'Cruz, L. M., Vollmann, E. H., Hinterberger, M., Emmerich, J., Swee, L. K., Rolink, A., and Klein, L. (2007). Selection of Foxp3+ regulatory T cells specific for self antigen expressed and presented by Aire+ medullary thymic epithelial cells. Nat. Immunol. 8, 351-358.

Aujla, S. J., Chan, Y. R., Zheng, M., Fei, M., Askew, D. J., Pociask, D. A., Reinhart, T. A., Mcallister, F., Edeal, J., Gaus, K., Husain, S., Kreindler, J. L., Dubin, P. J., Pilewski, J. M., Myerburg, M. M., Mason, C. A., Iwakura, Y., and Kolls, J.
K. (2008). IL-22 mediates mucosal host defense against Gram-negative bacterial pneumonia. Nat. Med. 14, 275-281.

Bajenoff, M., Glaichenhaus, N., and Germain, R. N. (2008). Fibroblastic reticular cells guide $\mathrm{T}$ lymphocyte entry into and migration within the splenic T cell zone. J. Immunol. 181, 3947-3954.

Bautista, J. L., Lio, C. W., Lathrop, S. K., Forbush, K., Liang, Y., Luo, J., Rudensky, A. Y., and Hsieh, C. S. (2009). Intraclonal competition limits the fate determination of regulatory $\mathrm{T}$ cells in the thymus. Nat. Immunol. 10, 610-617.

Bennett, C. L., Christie, J., Ramsdell, F., Brunkow, M. E., Ferguson, P. J., Whitesell, L., Kelly, T. E., Saulsbury, F. T., Chance, P. F., and Ochs, H. D. (2001). The immune dysregulation, polyendocrinopathy, enteropathy, X-linked syndrome (IPEX) is caused by mutations of FOXP3. Nat. Genet. 27, 20-21.

Boehm, T., Scheu, S., Pfeffer, K., and Bleul, C. C. (2003). Thymic medullary epithelial cell differentiation, thymocyte emigration, and the control of autoimmunity require lympho-epithelial cross talk via LTbetaR. J. Exp. Med. 198, 757-769.

Brocker, T., Gulbranson-Judge, A., Flynn, S., Riedinger, M., Raykundalia, C., and Lane, P. (1999). CD4 T cell traffic control: in vivo evidence that ligation of OX40 on CD4 T cells by OX40-ligand expressed on dendritic cells leads to the accumulation of CD4 T cells in B follicles. Eur. J. Immunol. 29, 1610-1616.

Chin, R. K., Lo, J. C., Kim, O., Blink, S. E., Christiansen, P. A., Peterson,

\section{SUMMARY}

In summary, LTi are part of a family of innate lymphoid cells (ILCs) that we postulate had innate function in an ancestral immune system. However, through their expression of the more recently evolved TNF-ligands OX40L and CD30L, we believe that they have been adapted to sustain CD4 memory T cells. We report data showing that $\mathrm{T}_{\text {regs }}$ are dispensible in the absence of OX40 and $\mathrm{CD} 30$, and suggest that $\mathrm{CD} 4$ regulation co-evolved with effector function. Furthermore, we postulate that $\mathrm{T}_{\text {regs }}$ selected on selfantigen-expressing mTecs might also be maintained by LTi, like memory CD4 T cells, in peripheral lymphoid tissues, to ensure that inappropriate immune responses to self are not evoked.

\section{ACKNOWLEDGMENTS}

Peter J. L. Lane and Graham Anderson are supported by Program grants from the Medical Research Council and the Wellcome Trust. David R. Withers is supported by a career development fellowship from the Wellcome Trust.

P., Wang, Y., Ware, C., and Fu, Y. X. (2003). Lymphotoxin pathway directs thymic Aire expression. Nat. Immunol. 4, 1121-1127.

Croft, M. (2009). The role of TNF superfamily members in T-cell function and diseases. Nat. Rev. Immunol. 9, 271-285.

Eberl, G. (2005). Opinion: inducible lymphoid tissues in the adult gut: recapitulation of a fetal developmental pathway? Nat. Rev. Immunol. 5, 413-420.

Flores, M. V., Hall, C., Jury, A., Crosier, K., and Crosier, P. (2007). The zebrafish retinoid-related orphan receptor (ror) gene family. Gene Expr. Patterns 7, 535-543.

Fontenot, J. D., Gavin, M. A., and Rudensky, A. Y. (2003). Foxp3 programs the development and function of CD4+CD25+ regulatory $\mathrm{T}$ cells. Nat. Immunol. 4 , 330-336.

Futterer, A., Mink, K., Luz, A., KoscoVilbois, M. H., and Pfeffer, K. (1998). The lymphotoxin beta receptor controls organogenesis and affinity maturation in peripheral lymphoid tissues. Immunity 9, 59-70.

Gaspal, F., Bekiaris, V., Kim, M., Withers, D., Bobat, S., Maclennan, I., Anderson, G., Lane, P. J., and Cunningham, A. F. (2008). Critical synergy of CD30 and OX40 signals in CD4 $\mathrm{T}$ cell homeostasis and Th1 immunity to Salmonella. J. Immunol. 180, 2824-2829.

Gaspal, F. M., Kim, M. Y., Mcconnell, F. M., Raykundalia, C., Bekiaris, V., and Lane, P. J. (2005). Mice deficient in OX40 and CD30 signals lack memory antibody responses because of deficient CD4 T cell memory. J. Immunol. 174, 3891-3896.
Gaspal, F. M., Withers, D., Saini, M., Bekiaris, V., Mcconnell, F. M., White, A., Yagita, H., Walker, L. S. K., Anderson, G., and Lane, P. J. L. (2011). Abrogation of CD30 and OX40 signals prevents autoimmune disease in FoxP3 deficient mice. J. Exp. Med. 208, 1579-1584.

Georgopoulos, K., Bigby, M., Wang, J. H., Molnar, A., Wu, P., Winandy, S., and Sharpe, A. (1994). The Ikaros gene is required for the development of all lymphoid lineages. Cell 79, 143-156.

Glenney, G. W., and Wiens, G. D. (2007). Early diversification of the TNF superfamily in teleosts: genomic characterization and expression analysis. J. Immunol. 178, 7955-7973.

Guerau-de-Arellano, M., Martinic, M., Benoist, C., and Mathis, D. (2009). Neonatal tolerance revisited: a perinatal window for Aire control of autoimmunity. J. Exp. Med. 206, 1245-1252.

Hahn, M. E., Karchner, S. I., Shapiro, M. A., and Perera, S. A. (1997). Molecular evolution of two vertebrate aryl hydrocarbon (dioxin) receptors (AHR1 and AHR2) and the PAS family. Proc. Natl. Acad. Sci. U.S.A. 94, 13743-13748.

Hikosaka, Y., Nitta, T., Ohigashi, I., Yano, K., Ishimaru, N., Hayashi, Y., Matsumoto, M., Matsuo, K., Penninger, J. M., Takayanagi, H., Yokota, Y., Yamada, H., Yoshikai, Y., Inoue, J., Akiyama, T., and Takahama, Y. (2008). The cytokine RANKL produced by positively selected thymocytes fosters medullary thymic epithelial cells that express autoimmune regulator. Immunity 29, 438-450. 
Irla, M., Hugues, S., Gill, J., Nitta, T., Hikosaka, Y., Williams, I. R., Hubert, F. X., Scott, H. S., Takahama, Y., Hollander, G. A., and Reith, W. (2008). Autoantigen-specific interactions with $\mathrm{CD} 4+$ thymocytes control mature medullary thymic epithelial cell cellularity. Immunity 29, 451-463.

Kim, M. Y., Bekiaris, V., Mcconnell, F. M., Gaspal, F. M., Raykundalia, C., and Lane, P. J. (2005). OX40 signals during priming on dendritic cells Inhibit CD4 T cell proliferation: IL-4 switches off OX40 signals enabling rapid proliferation of Th2 effectors. J. Immunol. 174, 1433-1437.

Kim, M. Y., Gaspal, F. M., Wiggett, H. E., Mcconnell, F. M., GulbransonJudge, A., Raykundalia, C., Walker, L. S., Goodall, M. D., and Lane, P. J. (2003). CD4(+)CD3(-) accessory cells costimulate primed CD4 T cells through OX40 and CD30 at sites where $T$ cells collaborate with $B$ cells. Immunity 18, 643-654.

Kim, S., Han, S., Withers, D. R., Gaspal, F., Bae, J., Baik, S., Shin, H. C., Kim, K. S., Bekiaris, V., Anderson, G., Lane, P., and Kim, M. Y. (2011). CD117(+) CD3(-) CD56(-) OX40L(high) cells express IL-22 and display an LTi phenotype in human secondary lymphoid tissues. Eur. J. Immunol. 41, 1563-1572.

Kong, Y. Y., Yoshida, H., Sarosi, I., Tan, H. L., Timms, E., Capparelli, C., Morony, S., Oliveira-Dos-Santos, A. J., Van, G., Itie, A., Khoo, W., Wakeham, A., Dunstan, C. R., Lacey, D. L., Mak, T. W., Boyle, W. J., and Penninger, J. M. (1999). OPGL is a key regulator of osteoclastogenesis, lymphocyte development and lymph-node organogenesis. Nature 397, 315-323.

Lane, P. J., Gaspal, F. M., Mcconnell, F. M., Kim, M.-Y., Anderson, G., and Withers, D. R. (2012). Lymphoid tissue inducer cells: innate cells critical for CD4 memory responses? Ann. N. Y. Acad. Sci. 1247, 1-15.

Lane, P. J. L., Gaspal, M. C., and Kim, M.-Y. (2005). Two sides of a cellular coin: $\mathrm{CD} 4+\mathrm{CD} 3-$ cells orchestrate memory antibody responses and lymph node organisation. Nat. Rev. Immunol. 5, 655-660.

Link, A., Vogt, T. K., Favre, S., Britschgi, M. R., Acha-Orbea, H., Hinz, B., Cyster, J. G., and Luther, S. A. (2007). Fibroblastic reticular cells in lymph nodes regulate the homeostasis of naive T cells. Nat. Immunol. 8 , 1255-1265.
Mebius, R. E. (2003). Organogenesis of lymphoid tissues. Nat. Rev. Immunol. 3, 292-303.

Metzger, T. C., and Anderson, M. S. (2011). Control of central and peripheral tolerance by Aire. Immunol. Rev. 241, 89-103.

Moran, A. E., Holzapfel, K. L., Xing, Y., Cunningham, N. R., Maltzman, J. S., Punt, J., and Hogquist, K. A. (2011). $\mathrm{T}$ cell receptor signal strength in Treg and iNKT cell development demonstrated by a novel fluorescent reporter mouse. J. Exp. Med. 208, 1279-1289.

Ohshima, Y., Tanaka, Y., Tozawa, H., Takahashi, Y., Maliszewski, C., and Delespesse, G. (1997). Expression and function of OX40 ligand on human dendritic cells. J. Immunol. 159, 3838-3848.

Pepper, M., Linehan, J. L., Pagan, A. J., Zell, T., Dileepan, T., Cleary, P. P., and Jenkins, M. K. (2010). Different routes of bacterial infection induce long-lived TH1 memory cells and short-lived TH17 cells. Nat. Immunol. 11, 83-89.

Qureshi, O. S., Zheng, Y., Nakamura, K. Attridge, K., Manzotti, C., Schmidt, E. M., Baker, J., Jeffery, L. E., Kaur, S., Briggs, Z., Hou, T. Z., Futter, C. E., Anderson, G., Walker, L. S., and Sansom, D. M. (2011). Transendocytosis of CD80 and CD86: a molecular basis for the cell-extrinsic function of CTLA-4. Science 332, 600-603.

Reinhardt, R. L., Khoruts, A., Merica, R., Zell, T., and Jenkins, M. K. (2001). Visualizing the generation of memory CD4 $\mathrm{T}$ cells in the whole body. Nature 410, 101-105.

Repass, J. F., Laurent, M. N., Carter, C., Reizis, B., Bedford, M. T., Cardenas, K., Narang, P., Coles, M., and Richie, E. R. (2009). IL7-hCD25 and IL7-Cre BAC transgenic mouse lines: new tools for analysis of IL-7 expressing cells. Genesis 47, 281-287.

Rossi, S. W., Kim, M. Y., Leibbrandt, A., Parnell, S. M., Jenkinson, W. E., Glanville, S. H., Mcconnell, F. M., Scott, H. S., Penninger, J. M., Jenkinson, E. J., Lane, P. J., and Anderson, G. (2007). RANK signals from $\mathrm{CD} 4(+) 3(-)$ inducer cells regulate development of Aireexpressing epithelial cells in the thymic medulla. J. Exp. Med. 204, 1267-1272.

Satoh-Takayama, N., Vosshenrich, C. A., Lesjean-Pottier, S., Sawa, S., Lochner, M., Rattis, F., Mention, J. J., Thiam, K., Cerf-Bensussan, N., Mandelboim, O., Eberl, G., and Di Santo, J. P. (2008). Microbial flora drives interleukin 22 production in intestinal
NKp46+ cells that provide innate mucosal immune defense. Immunity 29, 958-970.

Schmidt, E. M., Wang, C. J., Ryan, G. A., Clough, L. E., Qureshi, O. S. Goodall, M., Abbas, A. K., Sharpe, A. H., Sansom, D. M., and Walker, L. S. (2009). Ctla-4 controls regulatory $\mathrm{T}$ cell peripheral homeostasis and is required for suppression of pancreatic islet autoimmunity. J. Immunol. 182, 274-282.

Surh, C. D., and Sprent, J. (2008). Homeostasis of naive and memory $\mathrm{T}$ cells. Immunity 29, 848-862.

Tai, X., Cowan, M., Feigenbaum, L., and Singer, A. (2005). CD28 costimulation of developing thymocytes induces Foxp3 expression and regulatory $\mathrm{T}$ cell differentiation independently of interleukin 2. Nat. Immunol. 6, 152-162.

Takatori, H., Kanno, Y., Watford, W. T., Tato, C. M., Weiss, G., Ivanov, Ii, Littman, D. R., and O'Shea, J. J. (2009). Lymphoid tissue inducerlike cells are an innate source of IL-17 and IL-22. J. Exp. Med. 206, 35-41.

Tsuji, M., Suzuki, K., Kitamura, H., Maruya, M., Kinoshita, K., Ivanov, Ii, Itoh, K., Littman, D. R., and Fagarasan, S. (2008). Requirement for lymphoid tissue-inducer cells in isolated follicle formation and $\mathrm{T}$ cell-independent immunoglobulin A generation in the gut. Immunity 29, 261-271.

Veldhoen, M., Hirota, K., Westendorf, A. M., Buer, J., Dumoutier, L., Renauld, J. C., and Stockinger, B. (2008). The aryl hydrocarbon receptor links TH17-cell-mediated autoimmunity to environmental toxins. Nature 453 , 106-109.

Walker, L. S., Gulbranson-Judge, A., Flynn, S., Brocker, T., Raykundalia, C., Goodall, M., Forster, R., Lipp, M. and Lane, P. (1999). Compromised OX40 function in CD28-deficient mice is linked with failure to develop CXC chemokine receptor 5-positive CD4 cells and germinal centers. $J$. Exp. Med. 190, 1115-1122.

Warren, W. C., Hillier, L. W., Marshall Graves, J. A., Birney, E., Ponting, C. P., Grutzner, F., Belov, K., Miller, W., Clarke, L., Chinwalla, A. T., Yang, S. P., Heger, A., Locke, D. P., Miethke, P., Waters, P. D., Veyrunes, F., Fulton, L., Fulton, B., Graves, T., Wallis, J., Puente, X. S., Lopez-Otin, C., Ordonez, G. R., Eichler, E. E., Chen, L., Cheng, Z., Deakin, J. E., Alsop, A., Thompson, K., Kirby, P., Papenfuss, A. T., Wakefield, M. J., Olender, T., Lancet, D., Huttley, G. A. Smit, A. F., Pask, A., Temple-Smith,
P., Batzer, M. A., Walker, J. A., Konkel, M. K., Harris, R. S., Whittington, C. M., Wong, E. S., Gemmell, N. J., Buschiazzo, E., Vargas Jentzsch, I. M., Merkel, A., Schmitz, J., Zemann, A., Churakov, G., Kriegs, J. O., Brosius, J., Murchison, E. P., Sachidanandam, R., Smith, C., Hannon, G. J., TsendAyush, E., Mcmillan, D., Attenborough, R., Rens, W., Ferguson-Smith, M., Lefevre, C. M., Sharp, J. A., Nicholas, K. R., Ray, D. A., Kube, M., Reinhardt, R., Pringle, T. H., Taylor, J., Jones, R. C., Nixon, B., Dacheux, J. L., Niwa, H., Sekita, Y., Huang, X., Stark, A., Kheradpour, P., Kellis, M., Flicek, P., Chen, Y., Webber, C., Hardison, R., Nelson, J., HallsworthPepin, K., Delehaunty, K., Markovic, C., Minx, P., Feng, Y., Kremitzki, C., Mitreva, M., Glasscock, J., Wylie, T., Wohldmann, P., Thiru, P., Nhan, M. N., Pohl, C. S., Smith, S. M., Hou, S., Nefedov, M., de Jong, P. J., Renfree, M. B., Mardis, E. R., and Wilson, R. K. (2008). Genome analysis of the platypus reveals unique signatures of evolution. Nature 453, 175-183.

Watts, T. H. (2005). TNF/TNFR family members in costimulation of $\mathrm{T}$ cell responses. Annu. Rev. Immunol. 23, 23-68.

White, A. J., Nakamura, K., Jenkinson, W. E., Saini, M., Sinclair, C., Seddon, B., Narendran, P., Pfeffer K., Nitta, T., Takahama, Y., Caamano, J. H., Lane, P. J., Jenkinson, E. J., and Anderson, G. (2010). Lymphotoxin signals from positively selected thymocytes regulate the terminal differentiation of medullary thymic epithelial cells. J. Immunol. 185, 4769-4776.

Wildin, R. S., Ramsdell, F., Peake, J., Faravelli, F., Casanova, J. L., Buist, N., Levy-Lahad, E., Mazzella, M., Goulet, O., Perroni, L., Bricarelli, F. D., Byrne, G., Mceuen, M., Proll, S., Appleby, M., and Brunkow, M. E. (2001). X-linked neonatal diabetes mellitus, enteropathy and endocrinopathy syndrome is the human equivalent of mouse scurfy. Nat. Genet. 27, 18-20.

Williams, C. A., Murray, S. E., Weinberg, A. D., and Parker, D. C. (2007). OX40-mediated differentiation to effector function requires IL2 receptor signaling but not $\mathrm{CD} 28$, CD40, IL-12Rbeta2, or T-bet. J. Immunol. 178, 7694-7702.

Wing, K., Onishi, Y., Prieto-Martin, P., Yamaguchi, T., Miyara, M., Fehervari, Z., Nomura, T., and Sakaguchi, S. (2008). CTLA-4 control over Foxp3+ regulatory $\mathrm{T}$ cell function. Science 322, 271-275. 
Withers, D. R., Gaspal, F. M., Bekiaris, V., Mcconnell, F. M., Kim, M., Anderson, G., and Lane, P. J. (2011). OX40 and CD30 signals in CD4(+) T-cell effector and memory function: a distinct role for lymphoid tissue inducer cells in maintaining CD4(+) T-cell memory but not effector function. Immunol. Rev. 244, 134-148.

Withers, D. R., Jaensson, E., Gaspal, F., Mcconnell, F. M., Eksteen, B., Anderson, G., Agace, W. W., and Lane, P. J. (2009). The survival of memory CD4+ $\mathrm{T}$ cells within the gut lamina propria requires OX40 and CD30 signals. J. Immunol. 183, 5079-5084.

Wolk, K., Kunz, S., Witte, E., Friedrich, M., Asadullah, K., and Sabat, R. (2004). IL-22 increases the innate immunity of tissues. Immunity 21, 241-254.

Yokota, Y., Mansouri, A., Mori, S., Sugawara, S., Adachi, S., Nishikawa, S., and Gruss, P. (1999). Development of peripheral lymphoid organs and natural killer cells depends on the helix-loop-helix inhibitor Id2. Nature 397, 702-706.
Conflict of Interest Statement: The authors declare that the research was conducted in the absence of any commercial or financial relationships that could be construed as a potential conflict of interest.

Received: 14 November 2011; paper pending published: 28 November 2011; accepted: 08 February 2012; published online: 29 February 2012.

Citation: Lane PJL, Gaspal FM, McConnell FM, Withers DR and Anderson $G$ (2012) Lymphoid tissue inducer cells: pivotal cells in the evolution of
CD4 immunity and tolerance? Front Immun. 3:24. doi: 10.3389/fimmu.2012. 00024

This article was submitted to Frontiers in Inflammation, a specialty of Frontiers in Immunology.

Copyright (C) 2012 Lane, Gaspal, McConnell, Withers and Anderson. This is an open-access article distributed under the terms of the Creative Commons Attribution Non Commercial License, which permits non-commercial use, distribution, and reproduction in other forums, provided the original authors and source are credited. 